\title{
Tracking bluefin tuna reproductive migration into the Mediterranean Sea with electronic pop-up satellite archival tags using two tagging procedures
}

\author{
FRANCISCO J. ABASCAL $,{ }^{1 *}, \dagger$ ANTONIO \\ MEDINA, ${ }^{2}$ JOSÉ M. DE LA SERNA, ${ }^{3}$ DOLORES \\ GODOY $^{3}$ AND GUILLERMO ARANDA ${ }^{2}$ \\ ${ }^{1}$ Instituto Español de Oceanografía, PO Box 1373, 38180, \\ Santa Cruz de Tenerife, Spain \\ ${ }^{2}$ Departamento de Biología, Facultad de Ciencias del Mar y \\ Ambientales, Campus de Excelencia Internacional del Mar \\ (CEI·MAR), 11510, Puerto Real, Cádiz, Spain \\ ${ }^{3}$ Instituto Español de Oceanografía, PO Box 285, 29640, Fuen- \\ girola, Málaga, Spain
}

\begin{abstract}
Thirteen adult bluefin tuna were tracked with electronic pop-up satellite tags during their reproductive migration towards Mediterranean spawning grounds as they entered the Strait of Gibraltar. Fish were caught in tuna traps and tagged either underwater, with the aid of a modified spear gun, or on the deck of the boat. Fish tagged on board initially showed a shallower behavior than those tagged in the water. The pattern of horizontal movements was also different between both groups. Shortly after tagging, the eight fish tagged in the water entered the Mediterranean Sea. Six of these fish reached the spawning ground located southwest of the Balearic archipelago before heading back for the Atlantic, whereas the other two traveled farther east, reaching its easternmost longitudes between Formentera and Sardinia and the South Tyrrhenian Sea, respectively. In contrast, two out of the five fish tagged on board never entered the Mediterranean Sea, and another one did enter the Mediterranean when the reproductive season was already over. These results suggest an impact of the tagging procedure on the post-release behavior of bluefin tuna. Excluding the tags that popped-off east of the Strait of Gibraltar, bluefin tuna stayed in the Mediterranean Sea for 22 28 days. Analysis of the median depth indicated a

*Correspondence. e-mail: francisco.abascal@ca.ieo.es

$\dagger$ Present address: Secretariat of the Pacific Community PO

Box D5 98848 Noumea New Caledonia.

Received 21 January 2015

Revised version accepted 3 November 2015
\end{abstract}

shallow behavior during both day and nighttime throughout the return phase of the fish from the Mediterranean Sea to the Atlantic Ocean with the exception of the area around the Strait of Gibraltar, where they showed a deeper behavior that coincided with a marked vertical gradient in the currents.

Key words: Atlantic bluefin tuna, electronic tagging, pop-up satellite archival tags, Strait of Gibraltar, tracking

\section{INTRODUCTION}

The Atlantic bluefin tuna is the largest of all tunas (ICCAT 2006-2014) and one of the most highly priced fish species in the world (Ottolenghi et al., 2004). Bluefin tuna fishing has occurred for millennia in the Mediterranean Sea (Doumenge, 1998), taking advantage of the reproductive migration of the species from the foraging grounds in the Atlantic to the spawning areas in spring. The development of novel storage technologies (mainly deep freezing aboard carrier vessels in the 1970s) and, more recently, farming techniques, have increased the profitability of the fisheries and resulted in a sharp increase in the catches. This situation led to an overexploitation of the eastern bluefin tuna stock and boosted urgent management actions which, according to the latest assessment, are significantly improving the status of the population (ICCAT, 2014).

In spite of the management measures adopted, the knowledge of the exact stock status is still subject to important uncertainties. Some of the recommendations of ICCAT concerning bluefin tuna stock assessment include the need to collect fisheries-independent data, as well as improving the available information on maturity, reproduction and stock structure (ICCAT, 2013). In recent years, the outstanding technological development of electronic tags has provided new insight into the habitat preferences, migration patterns, stock structure and reproductive behavior of bluefin tuna. The first studies based on electronic tagging of Atlantic bluefin tuna were published in the late 1990s (Block et al., 1998; Lutcavage et al., 1999). 
Many studies have since contributed to improve our knowledge on the species' life history, although most of these initiatives took place in the western Atlantic Ocean (Lutcavage et al., 2000; Block et al., 2001, 2005; Wilson et al., 2005; Teo et al., 2007a,b; Walli et al., 2009; Wilson and Block, 2009; Galuardi et al., 2010; Galuardi and Lutcavage, 2012).

Although the Atlantic bluefin tuna eastern stock is far larger than the western population (Rooker et al., 2007), electronic tagging studies in the eastern Atlantic and Mediterranean have been scarce. Recently, Aranda et al. (2013a) described the diving behavior and post-reproductive migration of fish tagged during the spawning season around the Balearic Islands. Unlike the findings of this paper, further studies (Fromentin and Lopuszanski, 2014; Cermeño et al., 2015; and other references cited therein) have reported allyear-round residency of bluefin tuna in the central and western Mediterranean. The only study carried out in the eastern Atlantic (Semba and Takeuchi, 2009) was based on a single fish tagged off Ireland out of the reproductive season.

The main aim of this paper is to contribute to a better understanding of the reproductive migration patterns of bluefin tuna from the moment they leave the Atlantic Ocean and cross the Strait of Gibraltar heading for Mediterranean spawning grounds. The study is also intended to assess the effect of the tagging procedure on the fish behavior with a view to improve our interpretation of electronic tag data.

\section{MATERIAL AND METHODS}

Atlantic bluefin tuna, Thunnus thynnus (Linnaeus, 1758), were tagged in five of the tuna traps located in the Strait of Gibraltar area between 26 May and 16 June 2011 (Table 1, Fig. 1). Tuna traps have taken advantage for centuries of the bluefin tuna's natural reproductive migration by conveying the fish to the main body of the gear through a series of long nets set perpendicular to the coastline. Once in the main body of the trap, the fish are driven to the 'death chamber', the only compartment of the trap structure fitted with a bottom net which can be lifted to harvest the catch. To facilitate the tagging operations, the net was raised to bring the fish close to the surface, and once they were tagged the chamber was opened to set them free. Upon skippers' advice, efforts were made to tag the fish that had entered the trap more recently, which seemingly schooled apart and displayed a quieter behavior, but because of the characteristics of this gear it was impossible to precisely determine the date the fish had entered the trap.
A total of 24 bluefin tuna were tagged (Table 1). Twelve fish were tagged underwater with the aid of a modified spear gun by adapting the tip of the shaft to fit the dart. Another 12 fish were grabbed by the divers, placed on a stretcher and hauled on board one of the trap support vessels for tagging. Pop-up satellite archival tags (PSAT) (MK10; Wildlife Computers ${ }^{\circledR}$, Redmond, WA, USA) were attached to an umbrella plastic dart (Michael Domeier, pers. com.) by means of a monofilament leader with silicone tubing. The dart was inserted into the dorsal musculature at the base of the second dorsal fin. The body mass was estimated either visually by an experienced diver or from the fork length (Rodríguez-Roda, 1964), depending on whether the fish were tagged in the water or on the deck, respectively.

Tags were programmed to summarize daily data on time-at-temperature and time-at-depth at predefined bins (Temperature: 5, 7, 9, 11, 13, 15, 17, 19, 21, 23, 25, 27 and $29^{\circ} \mathrm{C}$; Depth: 0, 10, 20, 50, 100, 150, 200, $300,400,500,600,700$ and $800 \mathrm{~m}$ ), and to release 365 days after deployment, or to detach in case of fish mortality or premature release, detected as more than 3 days at a constant depth. Tags were also programmed to record time-series of depth at 10-min intervals. The tags deployed in the trap of Larache (Morocco) were programmed to release if they stayed at a constant depth $\pm 8 \mathrm{~m}$ for more than $24 \mathrm{~h}$. The version of those tags did not allow for time-series recording.

Transmitted information was first processed using the manufacturer software (DAP processor; Wildlife Computers). Tracks were estimated by Collecte Localisation Satellite (CLS) using a Kalman filter/smoother approach constrained by light-level, sea surface temperature (daily fields obtained at a $9-\mathrm{km}$ resolution by blending microwave and infrared sea surface temperature (SST) from Remote Sensing Systems (Santa Rosa, CA, USA) and bottom topography (ETOPO2) as described by Royer and Lutcavage (2009). Only the tags that remained attached for more than 20 days were analyzed.

Linear mixed models (Bates et al., 2015), followed by ANOVA, were performed to test the effect of longitude (rounded to the closest degree) on the median vertical depth of fish during day and nighttime, respectively. As a result of the potential effect of tagging on fish behavior, the residency of some fish in certain areas and the potential for different behavior between the entry and exit phases, the analyzes were restricted to the data recorded during the exit from the Mediterranean Sea to the Atlantic Ocean.

Zonal current data were downloaded from the Copernicus Marine Environment Monitoring 
Table 1. Summary of tag deployments.

\begin{tabular}{|c|c|c|c|c|c|c|c|c|}
\hline \multirow[b]{2}{*}{ Tag no. } & \multirow[b]{2}{*}{ Tagging date } & \multirow[b]{2}{*}{ Trap } & \multirow{2}{*}{$\begin{array}{c}\text { Estimated } \\
\text { weight }(\mathrm{kg})\end{array}$} & \multirow[b]{2}{*}{ Report date } & \multirow[b]{2}{*}{ DAL } & \multicolumn{2}{|c|}{ Report position } & \multirow[b]{2}{*}{ Notes } \\
\hline & & & & & & Lat & Lon & \\
\hline \multicolumn{9}{|c|}{ Tagged in the water } \\
\hline 66938 & $27 / 05 / 2011$ & Tarifa & 170 & $24 / 06 / 2011$ & 28 & $36^{\circ} 42^{\prime} \mathrm{N}$ & $000^{\circ} 38^{\prime} \mathrm{W}$ & \\
\hline 66953 & $27 / 05 / 2011$ & Tarifa & 180 & 06/06/2011 & 10 & $38^{\circ} 25^{\prime} \mathrm{N}$ & $004^{\circ} 35^{\prime} \mathrm{E}$ & \\
\hline 66954 & $27 / 05 / 2011$ & Tarifa & 170 & $17 / 08 / 2011$ & 82 & $50^{\circ} 18^{\prime} \mathrm{N}$ & $037^{\circ} 16^{\prime} \mathrm{W}$ & \\
\hline 66956 & 02/06/2011 & Zahara & 180 & 22/07/2011 & 50 & $35^{\circ} 14^{\prime} \mathrm{N}$ & $004^{\circ} 09^{\prime} \mathrm{W}$ & \\
\hline 66961 & $27 / 05 / 2011$ & Tarifa & 200 & 01/07/2011 & 35 & $35^{\circ} 46^{\prime} \mathrm{N}$ & $009^{\circ} 32^{\prime} \mathrm{W}$ & \\
\hline 66964 & $30 / 05 / 2011$ & Conil & 235 & $14 / 09 / 2011$ & 107 & $49^{\circ} 37^{\prime} \mathrm{N}$ & $032^{\circ} 48^{\prime} \mathrm{W}$ & \\
\hline 66965 & $27 / 05 / 2011$ & Tarifa & 280 & 28/08/2011 & 93 & $54^{\circ} 19^{\prime} \mathrm{N}$ & $021^{\circ} 24^{\prime} \mathrm{W}$ & $\dagger$ \\
\hline 67276 & 02/06/2011 & Zahara & 150 & $28 / 06 / 2011$ & 26 & $38^{\circ} 24^{\prime} \mathrm{N}$ & $000^{\circ} 18^{\prime} \mathrm{E}$ & \\
\hline 66941 & $27 / 05 / 2011$ & Tarifa & 180 & $20 / 06 / 2011$ & 24 & $39^{\circ} 4^{\prime} \mathrm{N}$ & $015^{\circ} 44^{\prime} \mathrm{E}$ & \\
\hline 66943 & $27 / 05 / 2011$ & Tarifa & 170 & $23 / 06 / 2011$ & 27 & $36^{\circ} 00^{\prime} \mathrm{N}$ & $000^{\circ} 38^{\prime} \mathrm{W}$ & \\
\hline 66944 & $27 / 05 / 2011$ & Tarifa & 200 & $04 / 06 / 2011$ & 8 & $37^{\circ} 19^{\prime} \mathrm{N}$ & $004^{\circ} 11^{\prime} \mathrm{E}$ & \\
\hline 66945 & $02 / 06 / 2011$ & Zahara & 220 & $29 / 08 / 2011$ & 88 & - & - & $\dagger$ \\
\hline \multicolumn{9}{|c|}{ Tagged on board } \\
\hline 66952 & $16 / 06 / 2011$ & Tarifa & 159 & - & - & - & - & \\
\hline 66939 & $16 / 06 / 2011$ & Barbate & 417 & - & - & - & - & \\
\hline 66962 & $16 / 06 / 2011$ & Tarifa & 263 & $19 / 06 / 2011$ & 3 & $36^{\circ} 01^{\prime} \mathrm{N}$ & $005^{\circ} 38^{\prime} \mathrm{W}$ & \\
\hline 66963 & $16 / 06 / 2011$ & Barbate & 222 & 20/09/2011 & 96 & $44^{\circ} 54^{\prime} \mathrm{N}$ & $004^{\circ} 39^{\prime} \mathrm{W}$ & \\
\hline 66966 & $16 / 06 / 2011$ & Barbate & 211 & $19 / 06 / 2011$ & 3 & $36^{\circ} 09^{\prime} \mathrm{N}$ & $005^{\circ} 56^{\prime} \mathrm{W}$ & \\
\hline 66940 & $16 / 06 / 2011$ & Barbate & 222 & $30 / 09 / 2011$ & 106 & $38^{\circ} 40^{\prime} \mathrm{N}$ & $024^{\circ} 34^{\prime} \mathrm{W}$ & \\
\hline 66946 & $16 / 06 / 2011$ & Tarifa & 147 & $13 / 10 / 2011$ & 119 & $36^{\circ} 15^{\prime} \mathrm{N}$ & $004^{\circ} 31^{\prime} \mathrm{W}$ & \\
\hline 66951 & $16 / 06 / 2011$ & Tarifa & 150 & $11 / 07 / 2011$ & 25 & $37^{\circ} 01^{\prime} \mathrm{N}$ & $007^{\circ} 42^{\prime} \mathrm{W}$ & $*$ \\
\hline 70601 & 26/05/2011 & Larache & 221 & $30 / 06 / 2011$ & 35 & $30^{\circ} 38^{\prime} \mathrm{N}$ & $023^{\circ} 43^{\prime} \mathrm{W}$ & $\S$ \\
\hline 70604 & $26 / 05 / 2011$ & Larache & 230 & $28 / 05 / 2011$ & 2 & $35^{\circ} 18^{\prime} \mathrm{N}$ & $006^{\circ} 11^{\prime} \mathrm{W}$ & $\S$ \\
\hline 55003 & $26 / 05 / 2011$ & Larache & 235 & $29 / 05 / 2011$ & 3 & $35^{\circ} 22^{\prime} \mathrm{N}$ & $006^{\circ} 50^{\prime} \mathrm{W}$ & $\S$ \\
\hline 54563 & $26 / 05 / 2011$ & Larache & 227 & 03/08/2011 & 69 & $50^{\circ} 57^{\prime} \mathrm{N}$ & $028^{\circ} 44^{\prime} \mathrm{W}$ & $\S$ \\
\hline
\end{tabular}

DAL, days at liberty.

†Very few messages transmitted. No useful information retrieved.

*Tag recaptured in a tuna trap in Portugal. Did not get to transmit.

$\S$ The version of these tags did not allow for time-series generation.

Service (available online at http://marine.copernicus.eu/). The velocity fields for July 2013 (the first year available in the series) between $35^{\circ}$ and $40^{\circ}$ north were averaged by time and latitude to illustrate the zonal currents by longitude and depth in the study area.

Maps, plots and statistical analyzes were performed in R (R Core Team, 2013).

\section{RESULTS}

Tag reporting and retention

Two of the 12 tags deployed in the water (\#66965 and \#66945) transmitted very few messages, in one case not even providing a pop-off position; therefore, no useful information could be retrieved from them. Tags \#66953 and \#66944 showed ample vertical movements, from the surface to $200-500$ m every day, until they detached, floated to the surface and started reporting 8 and 10 days after tagging, respectively.
The eight remaining tags stayed attached for $47 \pm 31$ (mean $\pm \mathrm{SD}$ ) days (Table 1).

Regarding the fish tagged on board, 2 out of the 12 tags (\#66952 and \#66939) did not report, four detached soon after tagging (less than 4 days), one was recaptured and failed to transmit (\#66951), and the remaining five stayed attached for $84 \pm 34$ days (Table 1). Two out of the four tags that detached shortly after tagging (\#66962 and 66966) remained at a constant depth, in the $20-50 \mathrm{~m}$ bin, for $24 \mathrm{~h}$ before they floated to the surface and started transmitting. Tag \#55003 showed a wide vertical distribution during the first day, from the surface to 150-200 m deep, and then floated to the surface. Finally, tag \#70604 stayed in the four-first depth bins (from the surface to $50 \mathrm{~m}$ ) before the premature release detection was triggered.

\section{Horizontal movements}

The fish tagged in the water entered the Mediterranean Sea shortly after tagging (Figures 1a and 2). Six of these 
Figure 1. Synthetic map showing the tracks followed by the fish tagged in the water (a) and on board (b) by month. The inset in (a) is an enlargement of the Strait of Gibraltar depicting the location of the five traps where tags were deployed (1, Conil; 2, Barbate; 3, Zahara; 4, Tarifa; and 5, Larache).
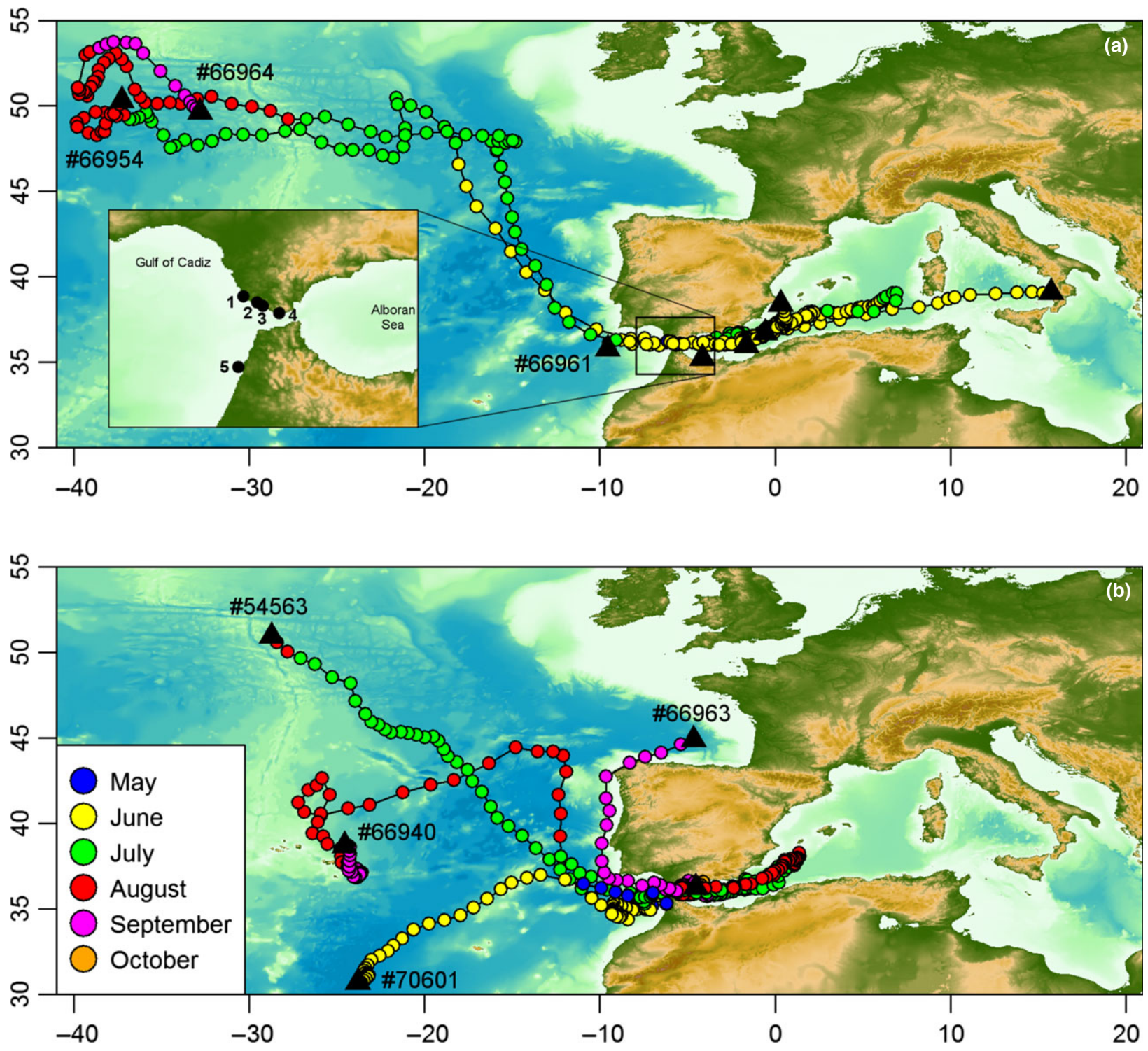

tags stayed west of $005^{\circ} \mathrm{E}$, between the Alboran Sea and the Balearic archipelago. Tags \#66938, \#66943 and \#67276 detached within the western Mediterranean by the end of June, whereas tags \#66954, \#66961 and \#66964 remained attached after the fish crossed the Strait of Gibraltar back to the Atlantic Ocean after 22, 28 and 27 days, respectively. Tag \#66961 detached and started transmitting a week later off Cape San Vicente (Portugal). Tags \#66954 and \#66964 initially traveled north-northwest and then moved west, staying in the latitudinal band of $45-55^{\circ} \mathrm{N}$, and not crossing the $040^{\circ} \mathrm{W}$ meridian. Tags \#66941 and \#66956 moved farther east. The former traveled eastwards until it popped off on 20th June in the South Tyrrhenian Sea. The latter reached its easternmost longitude at approximately $007^{\circ} \mathrm{E}$ in early July and then traveled back west until the tag detached and started transmitting on $22 \mathrm{nd}$ July from the western Alboran Sea.

The fish tagged on board showed a more variable horizontal behavior (Figures $1 \mathrm{~b}$ and 3 ). The two fish tagged in the trap of Larache by the end of May (\#70601 and \#54563) did not enter the Mediterranean Sea. Of these two fish, \#54563 remained in the IberoMoroccan Bay for around 1 month and by the end of 
June it started traveling northwest until the tag detached in early August around $51^{\circ} \mathrm{N}$ and $029^{\circ} \mathrm{W}$. Tag \#70601 initially moved west and then southwest, reaching an area centered at around $31^{\circ} \mathrm{N} 023^{\circ} \mathrm{W}$ by mid-June and staying there until the tag detached on 30th June. Tag \#66940 stayed 1 week in the Bay of
Cadiz and entered the Mediterranean Sea around the 23rd June, stayed southwest of the Balearic Islands and crossed the Strait of Gibraltar back to the Atlantic Ocean on 18th July, 25 days after its entrance into the Mediterranean. Fish \#66946 entered the Mediterranean Sea soon after tagging, reached its easternmost
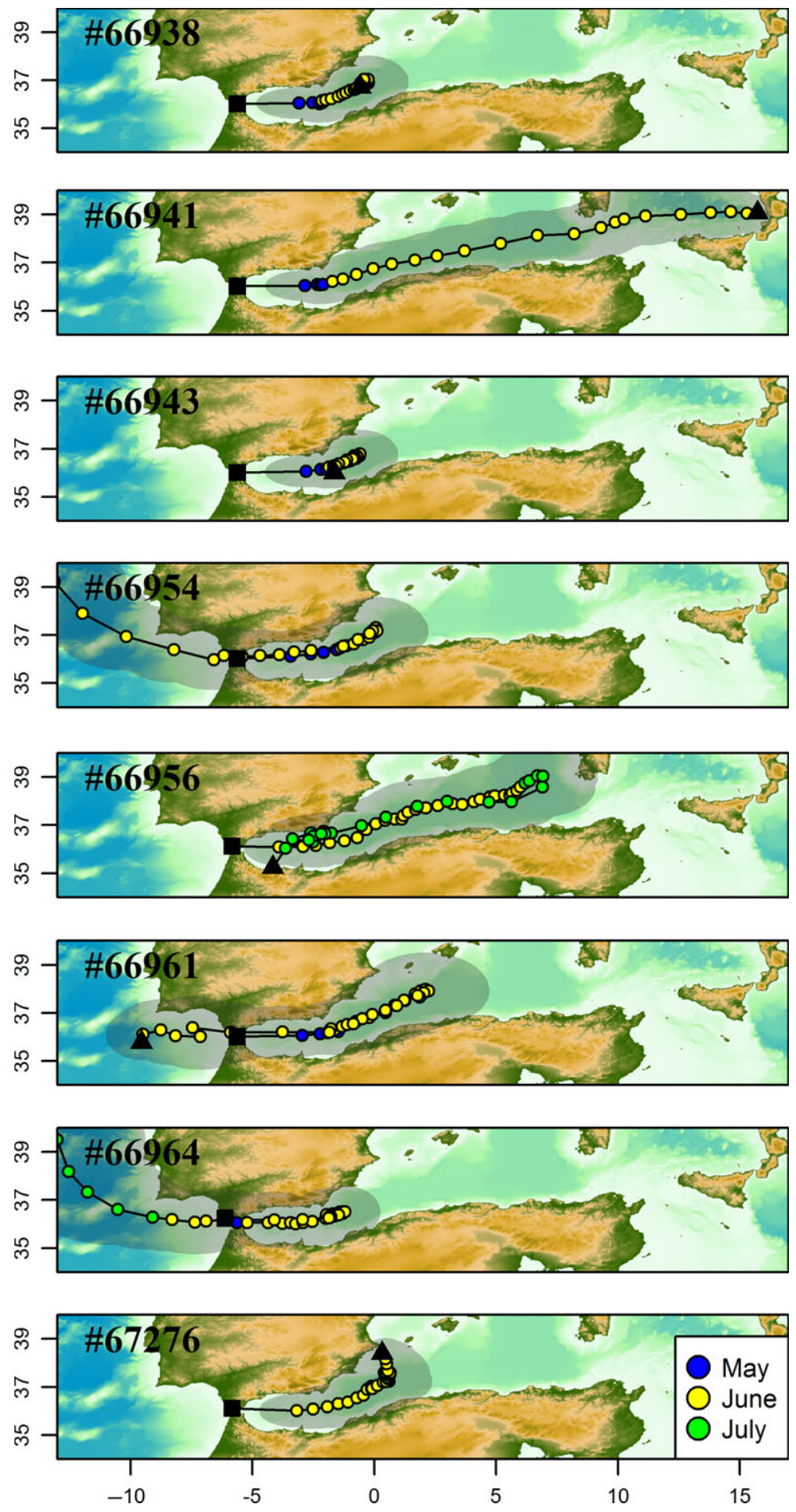

Figure 2. Individual tracks of fish tagged in the water by month.

(C) 2015 John Wiley \& Sons Ltd, Fish. Oceanogr., 25:1, 54-66. 
Figure 3. Individual tracks of fish tagged on board by month.
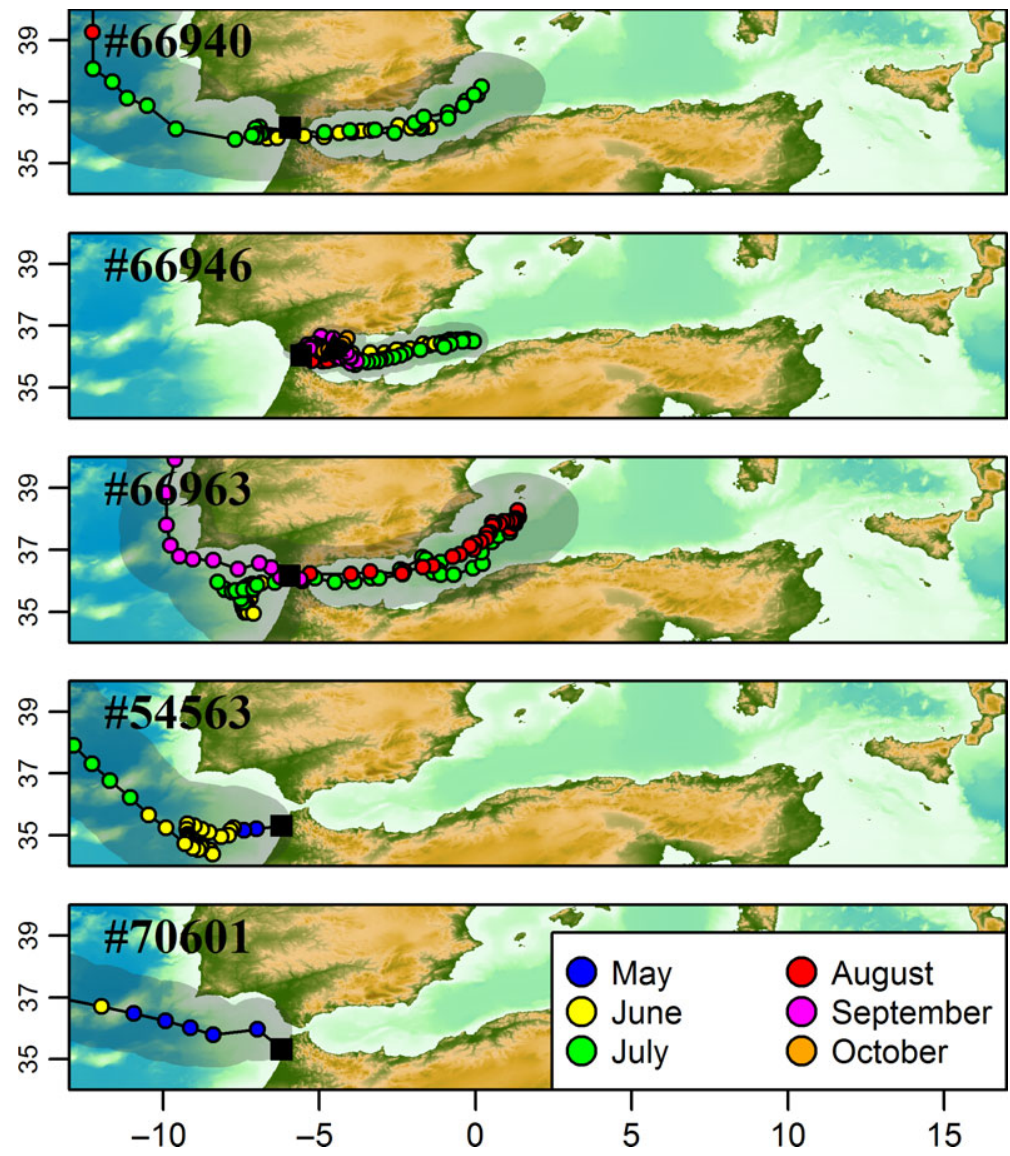

longitude, around the $0^{\circ}$ meridian, on 9th July and then moved back west. In early August, it returned to the Strait of Gibraltar but then remained in the westernmost Alboran Sea until the tag detached around mid-October. Finally, fish \#66963 stayed out of the Mediterranean Sea until $11^{\text {th }}$ July, then remained in the area of the Alboran Sea and the southwest of the Balearic archipelago until early September, when it reached the Atlantic Ocean and traveled north, surrounding the Iberian peninsula until the tag detached in the Bay of Biscay on 20th September.

\section{Vertical behavior}

Figure 4 illustrates the time-series of depth during the first week after release transmitted by six of the tags deployed in this study. These include the three tags deployed in the water that transmitted the larger number of messages, plus the only three tags deployed on board that generated time-series of depth. Overall, all the fish, especially those tagged in the water, showed a shallower behavior at nighttime than during the day. Although the information retrieved is quite patchy, the fish tagged on board seemed to stay in the upper part of the water column shortly after tagging, whereas all the fish tagged underwater performed dives below $200 \mathrm{~m}$ from the date of tagging.

The linear mixed model (Fig. 5) showed a significant effect (ANOVA, $P<0.01$ ) of longitude on the fish median depth during both day and nighttime, as the fish migrated from the Mediterranean Sea to the Atlantic Ocean. In general, the fish showed a shallow behavior, in the upper $50 \mathrm{~m}$ of the water column, along the fish tracks. However, deep dives were recorded when the fish were in the vicinity of the Strait of Gibraltar. The analysis of depth time-series (Fig. 6) reflected two distinct vertical behaviors within the Mediterranean Sea. East of c. $002^{\circ} \mathrm{W}$, the fish showed a predominant surface distribution, but when they entered the Alboran Sea in their westward migration, deep dives over $200 \mathrm{~m}$ became frequent during the daytime.

One of the fish tagged on board (\#66946) remained in the westernmost Alboran Sea from late July to midOctober, when the tag popped off. U-shaped profiles, with fish descending to depths over $200 \mathrm{~m}$ by dawn and returning to the surface before dusk, were consistently observed in this area. 
Figure 4. Depth time-series during the first week after tagging of fish in the water (three upper plots) and on board (three lower plots). Shaded areas indicate nighttime.
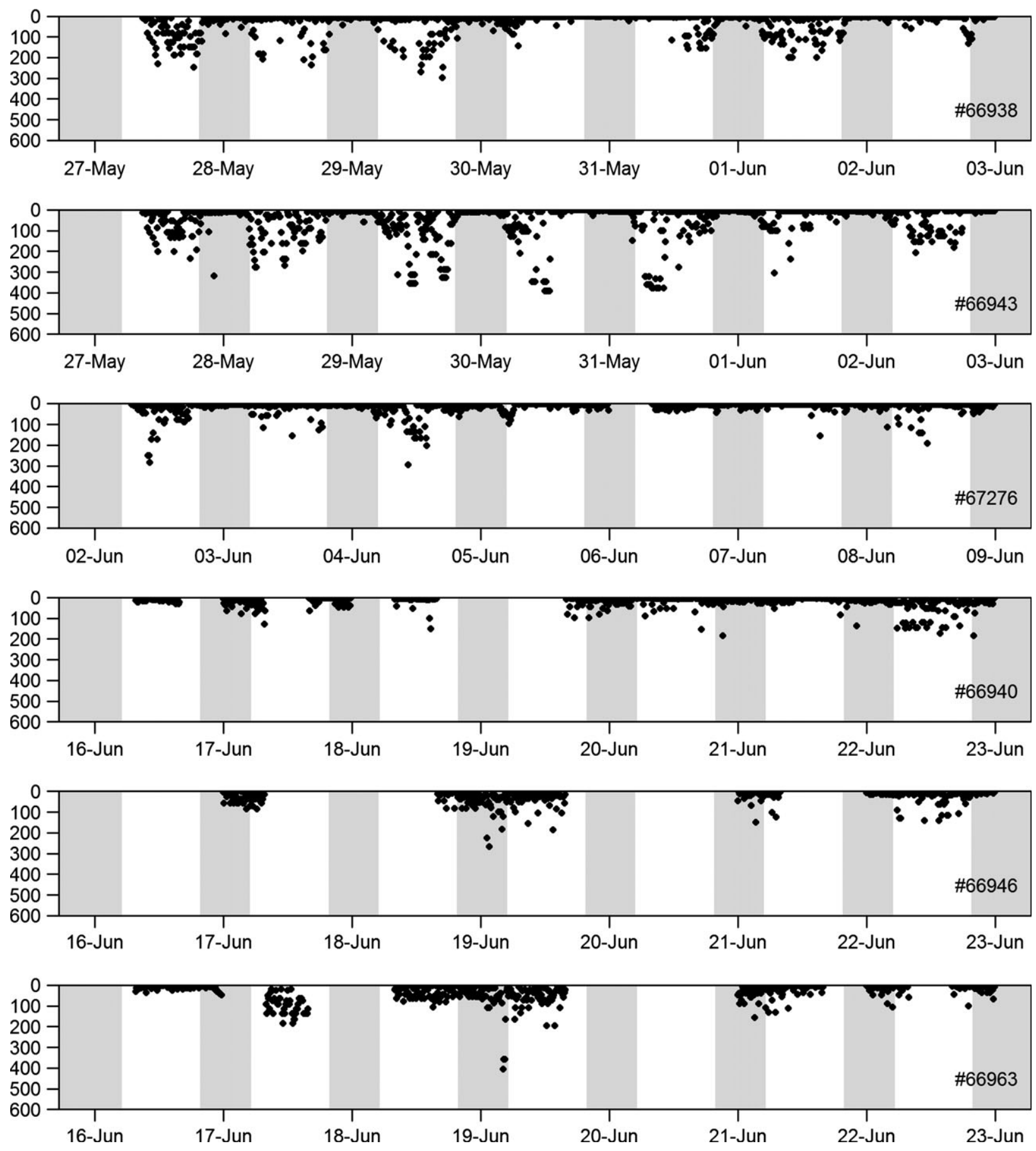

\section{DISCUSSION}

Tag reporting and retention

Four out of the 24 tags deployed in this study failed to transmit or transmitted very few messages and were, therefore, not usable. There may be diverse potential causes for signal failures, such as default in the saltwater switch, aerial breakage, predation and scavenging, fishing, etc. (e.g., Kerstetter et al., 2004; Hays et al., 2007; Fromentin and Lopuszanski, 2014; Cosgrove et al., 2015). The remaining 20 tags detached all before their preset date. In the case of two fish (20\%) 
Figure 5. Effect of longitude over fish median depth during the exit phase from the Mediterranean Sea to the Atlantic Ocean during night (a) and daytime (b), and average zonal currents in the region by longitude and depth (c).

(a)

Nighttime depth

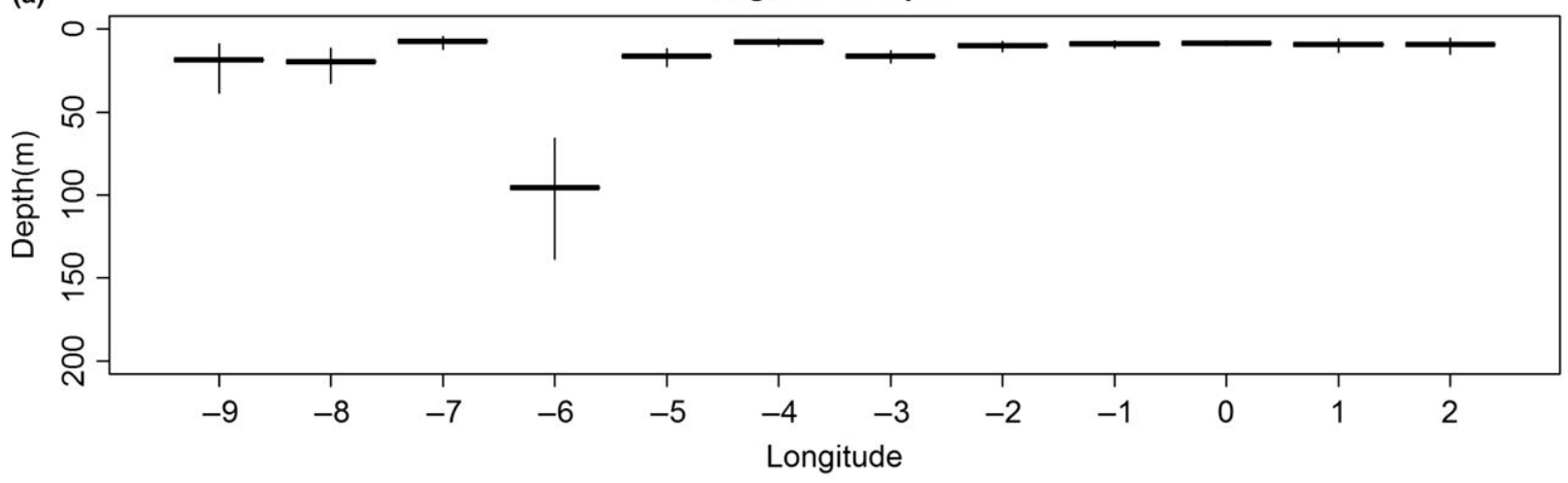

(b) Daytime depth
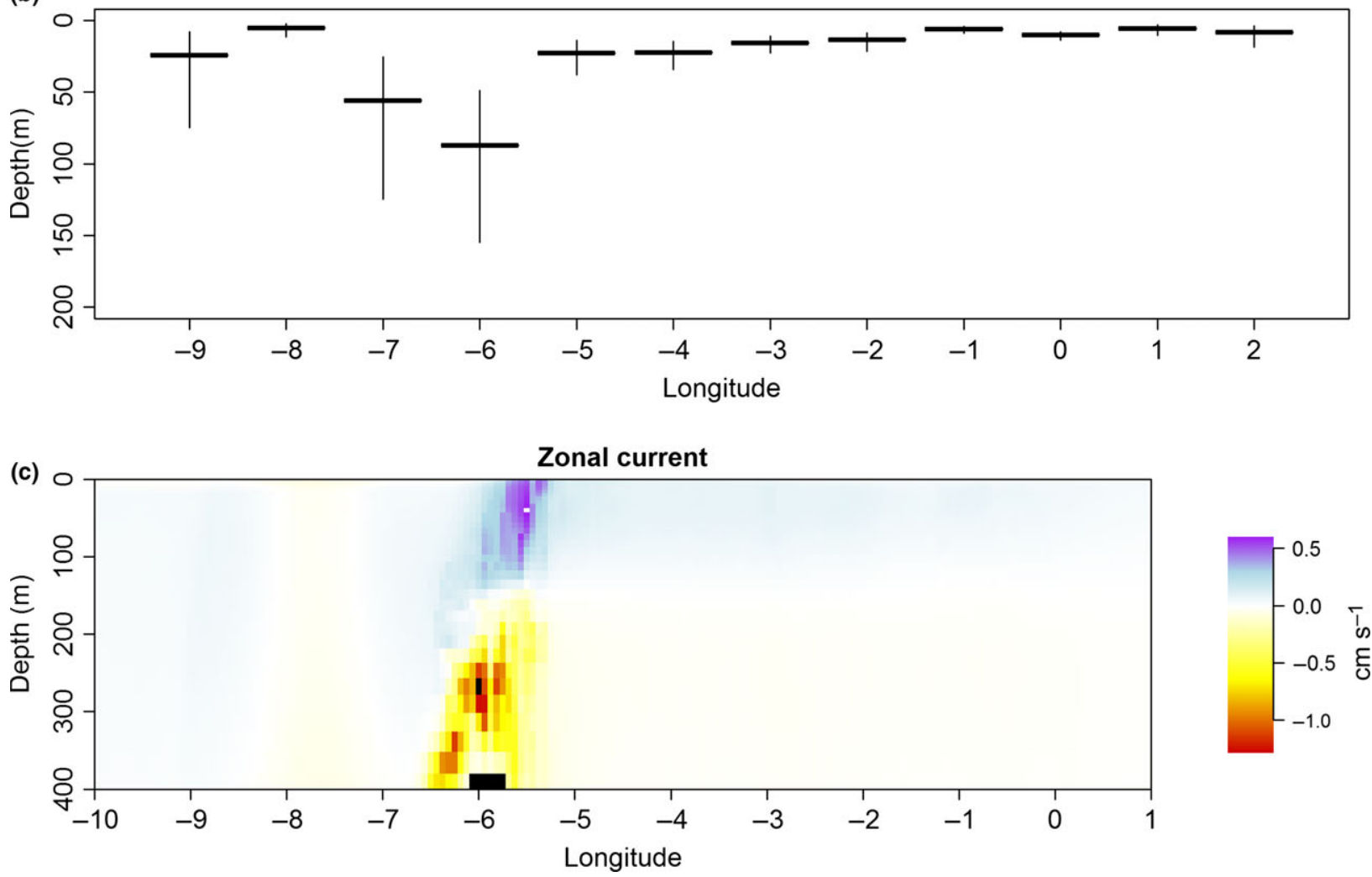

that had been tagged on board (tags \#66962 and \#66966), the data suggest that they died as a result of the tagging procedure and sank to the sea floor, where they remained until release was triggered after prolonged inactivity. Stokesbury et al. (2011) estimated a rather lower post-release mortality rate $(3.4 \%)$ in Atlantic bluefin tuna that had been tagged with PSAT tags and released without being brought on board the boat. The stress caused by the trap fishing operations and by taking the fish out of the water for tagging might significantly increase the mortality rate. The reason why the two other tags implanted on board detached as soon as 2 (\#70604) and 3 (\#55003) days later is unknown, although the vertical movement ranges do suggest that the fish were still alive when the tags popped off.

Excluding those tags that detached soon after tagging owing to either fish mortality or any other causes 
Figure 6. Depth time-series of three fish tagged underwater. The three upper plots correspond to areas east of $002^{\circ} \mathrm{W}$ and the three bottom plots cover the week after the day the fish crossed the $002^{\circ} \mathrm{W}$ meridian on their westward trophic migration. The vertical bars indicate the time when the fish crossed the Strait of Gibraltar, according to the geolocation estimates.
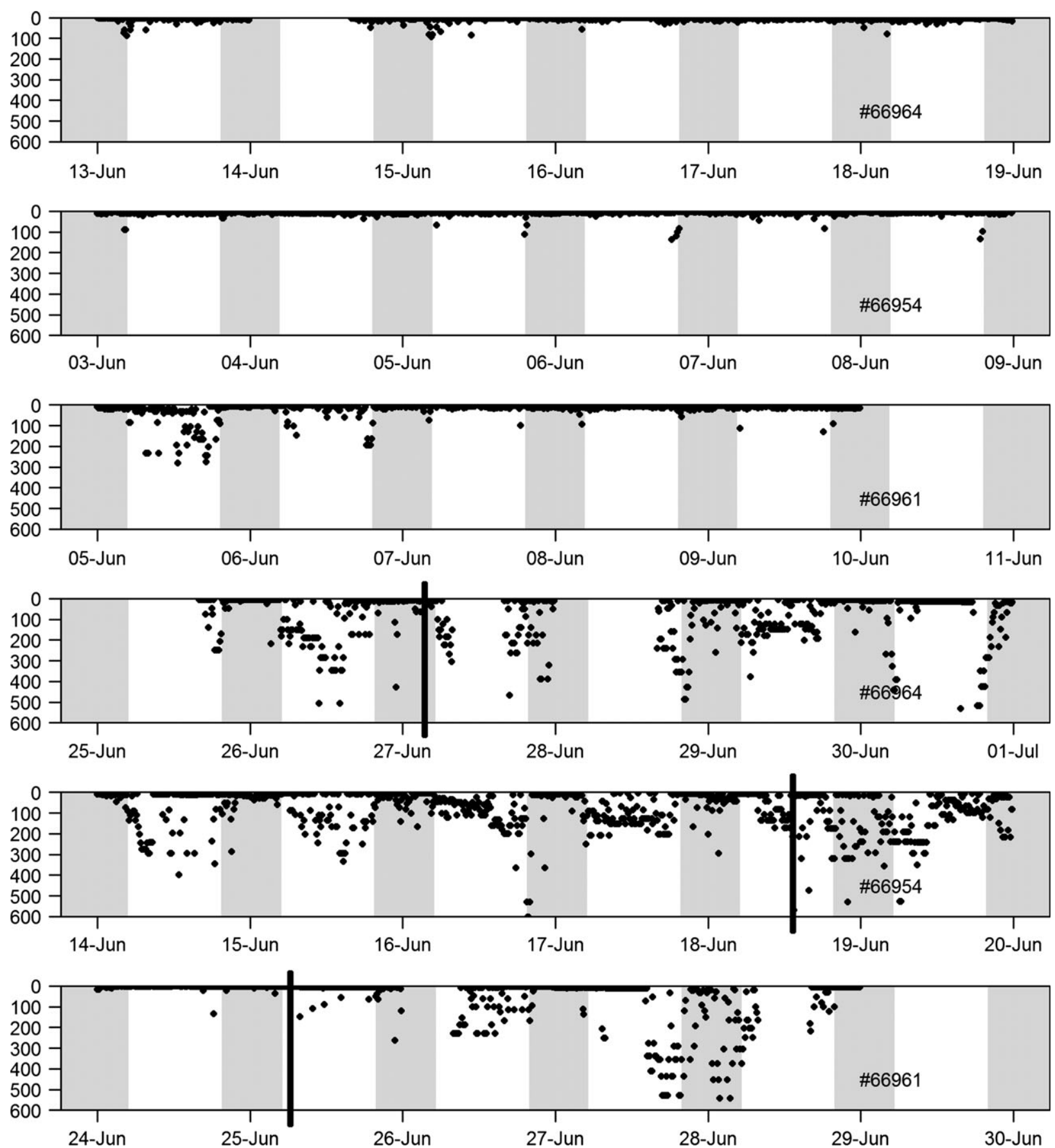

(e.g., bad insertion or tether damage during tagging), the tag retention time tended to be higher, although differences were not statistically significant ( $t$-test, $P=0.07)$, in fish tagged on board $(85 \pm 33$ days $)$ than it was in those tagged in the water
(48 \pm 35 days). This is probably because of a better insertion of the dart with the former method. In any case, the maximum retention time was 119 days, well below the 365 days initially programmed. Musyl et al. (2011) reviewed the performance of PSAT tags and 
reported premature detachment as a common problem among all the species analyzed. They pointed out several factors influencing tag retention and indicated biofouling and infection as the main issues to be addressed. In a more recent review specific to Atlantic bluefin tuna, Lutcavage et al. (2015) concluded that the most likely causes for tag failure are sea water infiltration, which makes transmission unfeasible, as well as inadequate tissue healing, inflammatory responses and inadequate anchor placement, all of which provoke early releases. Although Cosgrove et al. (2015) demonstrated predation of PSAT tags deployed on albacore (Thunnus alalunga), presumably by sharks, the risk of predation 'bites' appears to be low in Atlantic bluefin tuna (Lutcavage et al., 2015). However, it might be possible that tags are bitten off by other bluefin tuna when feeding in schools. In this regard, Rodríguez-Roda (1964) found the hydrostatic capsule of a tag deployed on a bluefin tuna in the stomach of another bluefin.

\section{Horizontal movements}

Differences in horizontal track patterns were found between the fish tagged on board and those tagged in the water (Figures $1 ; \mathrm{S} 1$ ). The fish used in this experiment entered the traps as they were migrating towards the breeding grounds in the Mediterranean Sea. Therefore, they were expected to keep swimming eastward after being released. While all the fish tagged in the water did enter the Mediterranean Sea, two out of the five fish tagged on board took the opposite direction, and of the remaining three tagged fish one came into the Mediterranean once the reproductive season was over, and another one did it 1 week after tagging. One plausible explanation for this behavior is that the stress produced by handling the fish could cause alterations in their migratory behavior. Westward movements were also observed by Rodríguez-Roda (1964) in pre-spawning bluefin tuna tagged in the trap off Barbate (southern Spain), which were recaptured 12 days later in the Portuguese trap of Tavira. These behaviors were regarded as anomalies as a result of tagging and disorientation. It should be noted that, as indicated above, it was not possible to determine the exact date the fish entered the trap, and that three out of the five deployments took place by mid-June. Therefore, other causes, such as stress related to fish confinement in the traps or an effect in the reproduction schedules cannot be definitely ruled out.

Nine out of the 11 fish that entered the Mediterranean Sea stayed in the westernmost basin, with only two traveling east of $002^{\circ} \mathrm{E}$. This might indicate that most of the fish crossing the Strait of Gibraltar, at least by the end of the migration period, which traditionally takes place between the end of April and mid-June (Rodríguez-Roda, 1964; Medina et al., 2002; Heinisch et al., 2008), spawn between the Balearic archipelago and the Alboran Sea. During the same fishing campaign (spring of 2011), Aranda et al. (2013a) described presumptive spawning profiles in PSAT. tagged bluefin tuna while they stayed between the Balearic archipelago and the Alboran Sea, and estimated a spawning frequency of $80 \%$ in this area. If we consider that the fish staying east of Alboran (i.e., east of $002^{\circ} \mathrm{W}$ ) are at the spawning phase, then the estimated duration of the spawning period of the fish bearing tags \#66954, \#66961 and \#66964 (whose respective estimated weights were 170,200 and $235 \mathrm{~kg}$ ) would be 15, 26 and 17 days, respectively. If we also assume that the relative batch fecundity of bluefin tuna in the Balearic spawning ground estimated from postovulatory follicles (approximately 48 eggs per gram of body weight) is constant irrespective of the fish size (Aranda et al., 2013b), these three tuna could have released, respectively, around 98, 200 and 153 million eggs.

The present results support previous PSAT tag observations suggesting that bluefin tuna that stay in the western Mediterranean during the spawning season return to the Atlantic as soon as the reproductive activity is completed (Aranda et al., 2013a). They contrast, however, with other studies which have described residency in the Mediterranean Sea (De Metrio et al., 2001, 2002, 2005a,b; Tudela et al., 2011; Fromentin and Lopuszanski, 2014; Cermeño et al., 2015; Quílez-Badia et al., 2015). None of the eight bluefin tuna tagged with PSAT tags by Cermeño et al. (2015) in the northwestern Mediterranean or the Adriatic seas left the Mediterranean during the tracking period, nor did it the single juvenile fish tagged with an archival tag in the northwestern Mediterranean and tracked for more than $1 \mathrm{yr}$. Similarly, none of 39 bluefin tuna tagged in the Gulf of Lions from August to early November (Fromentin and Lopuszanski, 2014) left for the North Atlantic during the tracking period. Such discrepancies support the idea that the stock structure of Atlantic bluefin tuna is more complex than the current assumption of two stocks (Cury et al., 1998), and favor the hypothesis of distinct subpopulations within the Mediterranean Sea (e.g., Fromentin and Powers, 2005; Rooker et al., 2007; Riccioni et al., 2010; Fromentin and Lopuszanski, 2014; Quílez-Badia et al., 2015).

There is little information on fish movements between the Atlantic Ocean and the easternmost Mediterranean basin. To our knowledge, the only 
exception is one archival tag that had been deployed off North Carolina and was recaptured almost 3 yrs later south of Cyprus (Walli et al., 2009). Further studies, especially those comprising tag deployments throughout the trap fishing season, are, therefore, needed to help clarify Atlantic-East Mediterranean connectivity in bluefin tuna populations.

\section{Vertical behavior}

Depth time-series revealed a diel pattern in fish depth behavior. A similar pattern, with fish staying in the mixed layer at night and foraging at depth during the daytime, has been thoroughly described for many mesopelagic predators, including the bluefin tuna (e.g., Teo et al., 2007a). Nevertheless, the vertical behavior of bluefin tuna during the reproductive season appears to vary significantly throughout different regions of the migratory routes. Thus, this diel pattern was not evident in some of the fish soon after tagging (Fig. 4), or when the fish were in the spawning grounds (Fig. 6). In contrast with the findings of Wilson and Block (2009), the time-series did not indicate that the fish swam at greater depths as they moved into the Mediterranean Sea from the Atlantic (Fig. 4). Otherwise, this deeper behavior was seen during the exit run (Fig. 6), as described by Aranda et al. (2013a). Some of the hypotheses proposed to explain this behavior are the use of currents for rheotactic orientation, predator avoidance, thermoregulation and energy saving. Moreover, we have observed that a deep behavior also occurs in the Alboran Sea area in comparison with the profiles obtained farther east. The complex circulation patterns caused by the exchange of Atlantic and Mediterranean waters and the effect of westerly winds on coastal water transport generate a quasi-permanent upwelling in the northwestern Alboran Sea, which in turn enhances the biological activity in the region (Reul et al., 2005) and might explain these behavioral differences in terms of feeding activity. Nevertheless, the analysis of median depths (Fig. 5) indicates that the fish stayed at shallow depths most of the time throughout the exit phase from the spawning grounds in the western Mediterranean to the eastern Atlantic Ocean, with the exception of the area around the Strait of Gibraltar, where the fish showed a deeper behavior both during the day and at nighttime. This deep pattern coincides with a clear gradient in the zonal currents in the area (Fig. 5c), with a net eastward flow of Atlantic water in the surface and an outflow of saltier Mediterranean water at greater depths.

The method of tagging carried out is also a significant source of variation in vertical profiles. Hoolihan et al. (2011) analyzed the post-release behavior of several pelagic species including PSAT-tagged bluefin tuna. Although they did not find behavioral modifications in the 11 bluefin tuna tracked in the Mediterranean, they acknowledged that irregular post-release behavior could have been missed because of the nature of the data (with low resolution and many gaps due to poor data transmission). Our results suggest that there is a different vertical behavior depending on the tagging technique used. It should be noted that the fish that were hauled on board were captured by hand by the divers, most of the times after they had entangled in the trap nets. This process is thought to be more traumatic than underwater tagging with a spear gun and, therefore, more likely to cause behavioral alterations in the tagged fish.

\section{ACKNOWLEDGEMENTS}

This study was funded by the Spanish Ministry of Agriculture, Food and Environment through the project 'Encomienda de gestión de la Secretaría General del Mar al Instituto Español de Oceanografía para el estudio del stock este de atún rojo, Thunnus thynnus, empleando las almadrabas españolas como observatorios científicos'. It has also been supported by a Marie Curie Intra-European Fellowship of the European Community's Seventh Framework Programme under contract number PIEF-GA-2012-326455. The work would not have been possible without the collaboration and advice from the owners and workers of the tuna traps. We also wish to thank Prof. Runge and two anonymous referees for useful suggestions that helped to improve the manuscript considerably. This is contribution $\# 109$ of CEI.MAR.

\section{REFERENCES}

Aranda, G., Abascal, F.J., Varela, J.L. and Medina, A. (2013a) Spawning behavior and post-spawning migration patterns of Atlantic bluefin tuna (Thunnus thynnus) ascertained from satellite archival tags. PLoS One 8:e76445.

Aranda, G., Medina, A., Santos, A., Abascal, F.J. and Galaz, T. (2013b) Evaluation of Atlantic bluefin tuna reproductive potential in the western Mediterranean Sea. J. Sea Res. 76:154-160.

Bates, D., Mächler, M., Bolker, B. and Walker, S. (2015) Fitting linear mixed-effects models using lme4. J. Stat. Softw. 67:148.

Block, B.A., Dewar, H., Farewell, C. and Prince, E.D. (1998) A new satellite technology for tracking the movements of Atlantic bluefin tuna. Proc. Natl Acad. Sci. USA 95:93849389.

Block, B.A., Dewar, H., Blackwell, S.B. et al. (2001) Migratory movements, depth preferences, and thermal biology of Atlantic bluefin tuna. Science 293:1310-1314. 
Block, B.A., Teo, S.L.H., Walli, A. et al. (2005) Electronic tagging and population structure of Atlantic bluefin tuna. Nature 434:1121-1127.

Cermeño, P., Quílez-Badia, G., Ospina-Álvarez, A. et al. (2015) Electronic tagging of Atlantic bluefin tuna (Thunnus thynnus, L.) reveals habitat use and behaviors in the Mediterranean Sea. PLoS One 10:e0116638.

Cosgrove, R., Arregui, I., Arrizabalaga, H., Goñi, N. and Neilson, J.D. (2015) Predation of pop-up satellite archival tagged albacore (Thunnus alalunga). Fish. Res. $162: 48-52$.

Cury, P., Anneville, A., Bard, F.X., Fonteneau, A. and Roy, C. (1998) Obstinate North Atlantic bluefin tuna (Thunnus thynnus thynnus): an evolutionary perspective to consider spawning migration. Col. Vol. Sci. Pap. ICCAT 50:239-247.

De Metrio, G., Arnold, G.P., de la Serna, J.M. et al. (2001) Further results of tagging Mediterranean bluefin tuna with pop-up satellite-detected tags. Col. Vol. Sci. Pap. ICCAT 52:776-783.

De Metrio, G., Arnold, G.P., Block, B.A. et al. (2002) Behaviour of post-spawning Atlantic bluefin tuna tagged with pop-up satellite tags in the Mediterranean and eastern Atlantic. Col. Vol. Sci. Pap. ICCAT 54:415-424.

De Metrio, G., Arnold, G.P., de la Serna, J.M. et al. (2005a) Movements of bluefin tuna (Thunnus thynnus) tagged in the Mediterranean Sea with pop-up satellite tags. Col. Vol. Sci. Pap. ICCAT 58:1337-1340.

De Metrio, G., Arnold, G.P., de la Serna, J.M. et al. (2005b) Movements and migrations of North Atlantic Bluefin tuna tagged with pop-up satellite tags. In Proceedings of the Fifth Conference on Fish Telemetry. M T Spedicato, G Lembo (eds) Rome: FAO/COISPA, pp. 161-168.

Doumenge, F. (1998) L'histoire des pêches thonières. Col. Vol. Sci. Pap. ICCAT 50:753-803.

Fromentin, J.-M. and Lopuszanski, D. (2014) Migration, residency, and homing of bluefin tuna in the western Mediterranean Sea. ICES J. Mar. Sci. 71:510-518.

Fromentin, J.-M. and Powers, J.E. (2005) Atlantic bluefin tuna: population dynamics, ecology, fisheries and management. Fish Fish. 6:281-306.

Galuardi, B. and Lutcavage, M. (2012) Dispersal routes and habitat utilization of juvenile Atlantic bluefin tuna, Thunnus thynnus, tracked with mini PSAT and archival tags. PLoS One 7:e37829.

Galuardi, B., Royer, F., Golet, W., Logan, J.M., Neilson, J. and Lutcavage, M. (2010) Complex migration routes of Atlantic bluefin tuna question current population structure paradigm. Can. J. Fish Aquat. Sci. 67:966-976.

Hays, G.C., Bradshaw, C.J.A., James, M.C., Lovell, P. and Sims, D.W. (2007) Why do Argos satellite tags deployed on marine animals stop transmitting? J. Exp. Mar. Biol. Ecol. 349:52-60.

Heinisch, G., Corriero, A., Medina, A. et al. (2008) Spatialtemporal pattern of bluefin tuna (Thunnus thynnus L. 1758) gonad maturation across the Mediterranean Sea. Mar. Biol. 154:623-630.

Hoolihan, J.P., Luo, J., Abascal, F.J. et al. (2011) Evaluating post-release behavior modification in large pelagic fish deployed with pop-up satellite archival tags. ICES J. Mar. Sci. 68:880-889.

ICCAT (2006-2014) ICCAT Manual. Madrid: ICCAT Publications on-line. URL http://www.iccat.int/en/ ICCATManual.asp [accessed 30 November 2015].
ICCAT (2013) Report of the 2012 Atlantic bluefin tuna stock assessment session. Col. Vol. Sci. Pap. ICCAT 69:1-198.

ICCAT (2014) Report of the Standing Committee on Research and Statistics (SCRS), 344 pp. Madrid, Spain (29 September-3 October 2014). URL http://www.iccat.es/Documents/ Meetings/Docs/2014-SCRS-REP_ENG.pdf [accessed 30 November 2015].

Kerstetter, D.W., Polovina, J.J. and Graves, J.E. (2004) Evidence of shark predation and scavenging on fishes equipped with pop-up satellite archival tags. Fish. Bull. 102:750-756.

Lutcavage, M.E., Brill, R.W., Skomal, G.B., Chase, B.C. and Howey, P.W. (1999) Results of pop-up satellite tagging of spawning size class fish in the Gulf of Maine: do North Atlantic bluefin tuna spawn in the mid-Atlantic? Can. J. Fish Aquat. Sci. 56:173-177.

Lutcavage, M.E., Brill, R.W., Skomal, G.B., Chase, B.C., Goldstein, J.L. and Tutein, J. (2000) Tracking adult North Atlantic bluefin tuna (Thunnus thynnus) in the northwestern Atlantic using ultrasonic telemetry. Mar. Biol. 137:347358.

Lutcavage, M.E., Lam, C.H. and Galuardi, B. (2015) Seventeen years and $\$ 3$ million dollars later: performance of PSAT tags deployed on Atlantic bluefin and bigeye tuna. Col. Vol. Sci. Pap. ICCAT 71:1757-1765.

Medina, A., Abascal, F.J., Megina, C. and García, A. (2002) Stereological assessment of the reproductive status of female Atlantic northern bluefin tuna, Thunnus thynnus (L.), during migration to Mediterranean spawning grounds through the Strait of Gibraltar. J. Fish Biol. 60:203-217.

Musyl, M.K., Domeier, M.L., Nasby-Lucas, N. et al. (2011) Performance of pop-up satellite archival tags. Mar. Ecol. Prog. Ser. 433:1-28.

Ottolenghi, F., Silvestri, C., Giordano, P., Lovatelli, A. and New, M.B. (2004) Capture-Based Aquaculture. The Fattening of Eels, Groupers, Tunas and Yellowtails. Rome: Food and Agriculture Organization of the United Nations, 308 pp.

Quílez-Badia, G., Ospina-Alvarez, A., Sainz-Trápaga, S., Di Natale, A., Abid, N. and Tudela, S. (2015) The WWF/ GBYP multi-annual bluefin tuna electronic tagging program (2008-2013): repercussions for management. Col. Vol. Sci. Pap. ICCAT 71:1789-1802.

R Core Team (2013) R: A Language and Environment for Statistical Computing. Vienna: R Foundation for Statistical Computing. URL http://www.R-project.org/ [accessed 30 November 2015].

Reul, A., Rodríguez, V., Jiménez-Gómez, F. et al. (2005) Variability in the spatio-temporal distribution and sizestructure of phytoplankton across the upwelling area in the NW-Alboran Sea, (W-Mediterranean). Cont. Shelf Res. 25:589-608.

Riccioni, G., Landi, M., Ferrara, G. et al. (2010) Spatiotemporal population structuring and genetic diversity retention in depleted Atlantic bluefin tuna of the Mediterranean Sea. Proc. Natl Acad. Sci. USA 107:21022107.

Rodríguez-Roda, J. (1964) Biología del atún, Thunnus thynnus (L.), de la costa sudatlántica de España. Inv. Pesq. 25:33-146.

Rooker, J.R., Alvarado Bremer, J.R., Block, B.A. et al. (2007) Life history and stock structure of Atlantic bluefin tuna (Thunnus thynnus). Rev. Fish. Sci. 15:265-310. 
Royer, F. and Lutcavage, M. (2009) Positioning pelagic fish from sunrise and sunset times: complex observation errors call for constrained, robust modeling. In: Tagging and Tracking of Marine Animals with Electronic Devices. Reviews: Methods and Technologies in Fish Biology and Fisheries, Vol. 9. J.L. Nielsen, H. Arrizabalaga, N. Fragoso, A. Hobday, M. Lutcavage \& J. Sibert (eds) New York, NY: Springer, pp. 323-341.

Semba, Y. and Takeuchi, Y. (2009) Preliminary result of pop-up archival tagging for Atlantic bluefin tuna (Thunnus thynnus) released in the northeastern Atlantic Ocean. Col. Vol. Sci. Pap. ICCAT 64:662-667.

Stokesbury, M.J.W., Neilson, J.D., Susko, E. and Cooke, S.J. (2011) Estimating mortality of Atlantic bluefin tuna (Thunnus thynnus) in an experimental recreational catchand-release fishery. Biol. Conserv. 144:2684-2691.

Teo, S.L.H., Boustany, A., Dewar, H. et al. (2007a) Annual migrations, diving behavior, and thermal biology of Atlantic bluefin tuna, Thunnus thynnus, on their Gulf of Mexico breeding grounds. Mar. Biol. 151:1-18.

Teo, S.L.H., Boustany, A. and Block, B.A. (2007b) Oceanographic preferences of Atlantic bluefin tuna, Thunnus thynnus, on their Gulf of Mexico breeding grounds. Mar. Biol. 152:1105-1119.

Tudela, S., Sainz-Trápaga, S., Cermeño, P., Hidas, E., Graupera, E. and Quílez-Badia, G. (2011) Bluefin tuna migratory behavior in the western and central Mediterranean Sea revealed by electronic tags. Col. Vol. Sci. Pap. ICCAT 66:1157-1169.

Walli, A., Teo, S.L.H., Boustany, A. et al. (2009) Seasonal movements, aggregations and diving behavior of Atlantic bluefin tuna (Thunnus thynnus) revealed with archival tags. PLoS One 4:e6151.

Wilson, S.G. and Block, B.A. (2009) Habitat use in Atlantic bluefin tuna Thunnus thynnus inferred from diving behavior. Endanger. Species Res. 10:355-367.

Wilson, S.G., Lutcavage, M.E., Brill, R.W., Genovese, M.P., Cooper, A.B. and Everly, A.W. (2005) Movements of bluefin tuna (Thunnus thynnus) in the northwestern Atlantic Ocean recorded by pop-up satellite archival tags. Mar. Biol. 146:409-423.

\section{SUPPORTING INFORMATION}

Additional Supporting Information may be found in the online version of this article:

Figure S1. Animation showing the tracks followed by bluefin tuna tagged in the water (blue) and on board (red). 